\title{
An Analytical Study of Quality of Work Life \& Organisational Commitment and Their Relation with Revenue per Employee of Major IT Companies in India
}

\author{
Radha Yadavi, Ashu Khanna², Priyanka Panday ${ }^{3}$, Sudipta Dasmohapatra ${ }^{3}$ \\ ${ }^{1}$ USB, Chandigarh University, Chandigarh, India \\ ${ }^{2}$ IIT Roorkee, Roorkee, India \\ ${ }^{3}$ Duke University, Durham, United States \\ Email: *priyanka.pandey13@gmail.com
}

How to cite this paper: Yadav, R., Khanna, A., Panday, P. and Dasmohapatra, S. (2019) An Analytical Study of Quality of Work Life \& Organisational Commitment and Their Relation with Revenue per Employee of Major IT Companies in India. Journal of Human Resource and Sustainability Studies, 7, 284-301.

https://doi.org/10.4236/jhrss.2019.72018

Received: April 10, 2019

Accepted: June 22, 2019

Published: June 25, 2019

Copyright $\odot 2019$ by author(s) and Scientific Research Publishing Inc. This work is licensed under the Creative Commons Attribution International License (CC BY 4.0).

http://creativecommons.org/licenses/by/4.0/

\section{(c) (i) Open Access}

\begin{abstract}
The purpose of the study is to find out the relation of quality of work life $(\mathrm{QWL})$ and organizational commitment $(\mathrm{OC})$ that engenders the financial performance of IT Companies in terms of revenue per employee. Data Collection is done through a combination of secondary and primary source. Primary data were collected by distributing questionnaire and collecting responses of participants. This paper emphasizes the data from secondary source and relates it with the findings from primary data. To analyze the performance in terms of revenue per employee of selected organizations, researcher segregates the revenue per employee of the IT companies in three levels i.e. highest Range revenue (above $\$ 10$ billion), Average range revenue (below $\$ 10$ billion and above $\$ 5$ billion) and Low range revenue (Below $\$ 5$ billion). Data are explained by using descriptive statistics and further analysis is done by regression analysis and ANOVA. Findings of the study say that there is significant relationship between quality of work life and organizational commitment with revenue per employee of IT companies.
\end{abstract}

\section{Keywords}

Quality of Work Life, Organizational Commitment, Organizational Performance and Revenue per Employee

\section{Introduction}

QWL defines the work atmosphere and should aim to enhance an employee's 
skills and abilities. Better QWL instills passion, enthusiasm, motivation and better interpersonal relationship among employees [1] [2] [3]. QWL is seen as an umbrella under which employees feel completely fulfilled at their workplace and amplify their wholehearted participation and cooperate with the administration in improving productivity and creating a healthy work environment [4] [5]. QWL boosts performance of an organisation as it depends on the efficiency of employees, relationship dynamics between superior-subordinate \& peer-peer and other variables like strategy, programs, processes and policies formed by management of the organization [3] [6]. All the things mentioned above relate to employees and hence employees play an important role in achieving goals and objectives of the organization [7] [8] [9]. Performance of the employees can be enhanced by improving QWL through execution of better human resource practices and policies [6]. Thus, it can be inferred that employee performance affects organizational performance significantly [10].

Information Technology (IT) sector has been one of the key drivers of India's GDP growth over the last 3 decades and contributes to nearly 13\% of the Indian gross domestic product (GDP) according to Indian GDP Report 2018. Since IT industry is a services business, the key asset is human capital and therefore Employees play the most important role in organization growth. However, over the last few years, the sector has witnessed growth slowdown due to rapid rise of digital technologies like IOT, AI, Cloud Computing, Blockchain, which has affected the traditional IT services business and has led to an increase in competitive intensity. This has led to slowdown in hiring, layoffs to make the organization lean, wage stagnation, etc. With the advancement of technology, organizations began putting resources to change the work environment in an attempt to make it conducive to the physical, mental, and social needs of their employees [11] [12] [13]. This is the primary reason to choose IT sector for this research. In the present time, it is crucial to estimate overall employee wellbeing based on factors like job security, job satisfaction, and work life balance. The aim of this study is to listen to employees of IT sector, investigate the factors that boost their performance, and to offer suggestions to improve their work-life balance. Today's organizations have been focusing on growth and profitability in line with the rise in popularity of "shareholder value creation" school of thought in corporate finance.

India is different from other countries in terms of work culture [14]. It is the need of the hour to develop pre-assignment induction programs, and to train employees to work in an inter-cultural environment prevalent in multinational companies [15]. Work culture has a direct effect on commitment among employees [16].

\section{Theoretical Background of the Concerned Variables}

The most ideal method for measurement of quality of work life is to gauge the degree in which individuals' happiness prerequisites are met, for example, ne- 
cessities which are fundamental in nature to make humans cheerful [17]. According to research, Quality of life is different in subjective and objective manners. A study on quality of life in research center of Denmark stated subjective and objective forms of quality of work life. When employees feel good and fully satisfied with the things around them, quality of work life is considered as subjective, while employees' satisfaction obtained through fulfillment of societal and cultural demands i.e. material wealth, social status and physical well-being, it is considered as objective part of the QWL. Because human beings are complex organisms, an adequate construction of the idea of human wellbeing must also be complex [18] [19] [20].

Most of the past research categorized Quality of work life into three aspects: being, belonging and becoming. "Being" defines the physical, psychological and spiritual aspect of human being whereas "belonging" defines the attachments like physical belonging, social, community and "becoming" covers practical, leisure and growth [21]. The domain of work life includes family, associates, work, locality (shelter), wellbeing, education, and spirituality. Union national development program published the annual Human Development Index (HDI) for many countries around the world. According to the 1997 report of human development program, the wellbeing of every country's citizen is scrutinized by measuring the following parameters:

- life expectancy;

- educational achievement;

- standard of living.

Quality of work life and quality of life (QOL) are the most significant and essential subjects for organizations, while manpower is the most important subsystem. Organizations consider them as an important priority [22] [23]. QOL could be defined as an individual's satisfaction with his/her life, compared to his/her ideal life where evaluation of the quality of life depends on individual's value system, social system and their cultural environment [24] [25] [26]. Various terms are given by various studies related to quality of life which included the following parameters: stratification and inequality, social inequality, wealth and income, poverty, socioeconomic status, and others [27] [28].

\subsection{Organization Performance and QWL}

Different meanings have been given to organizational performance making it difficult to analyze the performance in a standardized manner. Still, we can measure the overall performance of an organization by measuring the degree to which an organization fulfilled social requirements, accomplished their objectives and targets [27] [29] [30] [31]. Work, employees, and organizational structure were the primary focus for performance evaluation. Exploration of different avenues to evaluate organizational performance in the 1960s and 1970s led to defining it as the ability to exploit and access the limited resources present in an environment by the organization [21] [32]. In the 1980s and 1990s, the complexity of identifying organizational objectives was realized in a better way by man- 
agers as they identified that success is contingent to the accomplishment of goals (effectiveness) with minimum utilization of resources (efficiency) [33] [34] [35]. Hence, the concept of an organization achieving the set performance objectives, while operating in the constraints set by limited resources, was supported in the theories that followed by [36] [37]. Thus, profit was only one of the many indicators of performance [38] [39].

It can be said that organizational performance depends on how effectively people work on the given target and accomplish fruitful results. It has given an arrangement of definitions to outline the idea of organizational performance [39]. Performance is an arrangement of financial as well as nonfinancial indicators which offer data on the level of accomplishment of objectives and results [40] [41]. QWL enriches the performance of the organization [42].

To characterize the concept of performance, it is important to know its fundamental attribute of every range of obligation. To report an organization's performance level, it is important to have the capacity to measure the outcomes. A review and update of the recent financial analysis research covering human resource development by [43]. One study explains a positive relationship between human resources practices adopted by organization and the performance of the organization [44]. QWL in terms of quality of work life is further enhanced by the reinvestment of financial resources obtained by the increased growth and profitability by the management on employees. Result of the study also shows that organizational performance is positively correlated with work and performance of employees stated by [45] [46]. On the other hand, another research shows quality of work life does not have a significant relation with organizational performance [30] [47]. Psychological capital and its role on quality of work life, along with the performance of an organization were studied by [38] [39]. The results were that psychological capital of human resource of an organization considered as the most pertinent factor that plays a positive role in organizational performance. The relation between quality of work life and organizational performance is positively correlated with personality traits of the employees [48] [49] [50].

\subsection{Association of Organizational Performance with QWL and Commitment}

QWL plays a vital role in achieving the expected goals and objectives of the organization [22]. Organizational performance is a derivative of employee performance. Employee performance in turn is a function of organizational policies and programs which indirectly affect QWL in terms of quality of life. So, we can infer that Quality of work life of the employees affects the organizational performance significantly. According to the findings from past research, there is significant relationship between the QWL and organizational performance [38] [46] [48] [51] [52] [53]. The null hypothesis opted for this variable in the study as:

$H_{01}$ : The mean scores of QWL are identical across all selected IT companies; 
$H_{02}$ : The mean scores of organizational commitment are identical across all selected IT companies;

$H_{03}$ : There is no significant relationship between organizational performance and QWL and organisational Commitment.

\section{Research Methodology}

\subsection{Sample}

Research was performed in IT sector for the study due to massive IT workforce in India. Therefore, well-known IT firms in Bangalore, Delhi NCR, Chennai and Hyderabad were identified to collect the data. A cross sectional data was used in this study. The research was performed on 21 large Information Technology Companies.

All employees active on an organization's payroll at the time of study were eligible to participate in this research. A self-designed questionnaire was distributed to IT employees and 700 responses were received, out of which 618 responses were chosen for the data analysis refer to Table 1.82 responses were discarded due to many missing values and ambiguity.

Names of organizations are not included in the finding section to avoid conflict and ethical issues. The objective of the paper is to analyze the relation of Quality of work life and organizational commitment on the organizational performance in terms of revenue per employee. To accomplish the objective, researcher ranked the organizations on the basis of revenue per employee.

Table 1. Description of the IT companies.

\begin{tabular}{ccc}
\hline S. No. & Name of organization & $\begin{array}{c}\text { No. of questionnaires which were } \\
\text { correctly filled }\end{array}$ \\
\hline 1 & HCL Infosystem & 35 \\
2 & CMC Ltd. & 37 \\
3 & Tata Consultancy Services & 40 \\
4 & NIIT Ltd. & 22 \\
5 & Wipro Ltd. & 26 \\
6 & R Systems & 38 \\
7 & Mindtree & 31 \\
8 & Infinite Computer Solutions & 29 \\
9 & Igate Global Solutions & 27 \\
10 & Fiserv Services & 22 \\
11 & Zensar Technologies & 23 \\
12 & NEC. Corporation & 35 \\
13 & Infosys & 34 \\
14 & Tech Mahindra & 30 \\
15 & Oracle Corporation & 30 \\
16 & Hexaware Technologies & 30 \\
17 & Mphasis & 26 \\
18 & Cognizant Technologies & 33 \\
19 & Cyient Technologies & 32 \\
20 & Computer Science Corporation & 24 \\
21 & HCL Technologies & 14 \\
& Total & 618 \\
\hline
\end{tabular}




\subsection{Tools/Measures}

A self-designed questionnaire was used for the survey of large IT Companies. The initial selection of items included in the instrument was done by extensive review of literature. QWL is measured using a 63-item questionnaire which represented thirteen dimensions of QWL and three dimensions of organizational commitment. The thirteen dimensions used to measure QWL are Job satisfaction (JS) (3 questions, $\mathrm{a}=0.814)$, Participative management $(\mathrm{PM})$ (3 questions, $\mathrm{a}=0.720$ ), Peer relationship (PR) (4 items, a = 0.755), Superior relationship (SR) (3 questions, $\mathrm{a}=0.774$ ), Work Load (WL) (4 questions, a $=0.729)$, Safety and harassment $(\mathrm{SH})$ ( 3 questions, $a=0.620$ ), Rewards and recognition (RR) ( 3 items, $a=0.618$ ), Career growth (CG) (5 questions, $\mathrm{a}=0.701$ ), Communication (c) (3 questions, $\mathrm{a}=0.718$ ), Time pressure-TP (3 questions, $\mathrm{a}=0.729$ ), Pay-P ( 3 items, $\mathrm{a}=0.750$ ) and Work Life Balance-WLB (7 questions, $\mathrm{a}=0.760)$. Organizational Commitment OC is measured using 18 items are AC (6 questions, $\mathrm{a}=0.702$ ), Continuance Commitment (6 questions, $\mathrm{a}=0.688$ ), Normative Commitment NC (6 questions, $\mathrm{a}=$ 0.740). Organisation Performance OP is measured by the revenue per employee of the identical large IT Companies. Employees were asked to respond in a way that best described their feelings using a 5-point Likert's scales with 1 indicating strongly disagree, 2 disagree, 3 neutral, 4 agree and 5 strongly agree.

\subsection{Procedure}

As organizations and its employees are diverse, so the survey is customized to best fit each of the organization. It is felt that a varied approach would be more feasible for the organizations and that this would help maximize response rates. Participation is granted through prior appointments and consent via phone calls to the organization. The researcher visited the IT companies to administer the questionnaires. The participants are advised regarding the voluntary nature of participation. The data collected was analyzed by different statistical tools like descriptive statistics, multiple regressions using SPSS version 20 for Window.

\section{Results and Discussions}

\subsection{Descriptive Statistics of QWL and Commitment of the Individual Companies}

The study is done on 21 large IT companies; researcher analyzed the QWL and OC separately to compare there with the revenue per employee generated by the employees in the identical IT Company. Researcher segregates the revenue per employee of the IT companies in three levels i.e. Highest revenue (above $\$ 10$ billion), Average revenue (below $\$ 10$ billion and above $\$ 5$ billion) and Low revenue (Below $\$ 5$ billion). It is decided among the selected companies. All the respondents are from large cap IT companies. Companies selected for this study are chosen based on revenue i.e. companies whose revenues exceed $\$ 100$ million.

Table 2 shows the mean score and standard deviation of QWL and organizational commitment of each company individually. 
Table 2. Descriptive statistics of the individual IT companies

\begin{tabular}{|c|c|c|c|c|c|c|}
\hline \multirow[b]{2}{*}{ S. No. } & \multicolumn{3}{|c|}{ Mean } & \multicolumn{2}{|c|}{ Std. Deviation } & \multirow[b]{2}{*}{$\begin{array}{c}\text { Number of } \\
\text { Cases }\end{array}$} \\
\hline & RPE & QWL & Commitment & QWL & Commitment & \\
\hline 1 & High Range & 56.10 & 63.25 & 4.77 & 6.86 & 35.00 \\
\hline 2 & Low Range & 61.13 & 63.38 & 5.78 & 9.73 & 37.00 \\
\hline 3 & High Range & 60.29 & 65.37 & 4.42 & 6.90 & 40.00 \\
\hline 4 & Medium Range & 60.93 & 62.4 & 4.82 & 6.01 & 22.00 \\
\hline 5 & Medium Range & 59.78 & 63.62 & 4.04 & 6.60 & 26.00 \\
\hline 6 & Low Range & 59.15 & 62.37 & 5.13 & 8.92 & 38.00 \\
\hline 7 & Medium Range & 59.66 & 59.21 & 7.13 & 8.81 & 31.00 \\
\hline 8 & Low Range & 55.33 & 54.34 & 8.74 & 10.22 & 29.00 \\
\hline 9 & Low Range & 62.23 & 59.37 & 5.93 & 9.24 & 27.00 \\
\hline 10 & High Range & 63.08 & 65.00 & 6.16 & 13.82 & 22.00 \\
\hline 11 & Low Range & 59.97 & 59.17 & 6.41 & 10.51 & 23.00 \\
\hline 12 & Low Range & 59.86 & 57.54 & 8.51 & 9.28 & 35.00 \\
\hline 13 & High Range & 58.34 & 60.1 & 7.79 & 12.56 & 34.00 \\
\hline 14 & Medium Range & 59.58 & 62.44 & 7.83 & 13.02 & 30.00 \\
\hline 15 & Low Range & 57.15 & 49.24 & 7.54 & 10.25 & 30.00 \\
\hline 16. & Medium Range & 53.98 & 50.34 & 7.82 & 12.12 & 30.00 \\
\hline 17 & Medium Range & 56.28 & 50.06 & 8.50 & 10.61 & 26.00 \\
\hline 18 & High Range & 59.43 & 58.13 & 4.54 & 8.70 & 33.00 \\
\hline 19 & Medium Range & 59.65 & 60.21 & 3.93 & 6.93 & 32.00 \\
\hline 20 & Low Range & 58.61 & 57.23 & 4.10 & 8.60 & 24.00 \\
\hline 21 & Medium Range & 56.87 & 58.22 & 3.51 & 5.97 & 14.00 \\
\hline Total & & 59.04 & 59.40 & 6.56 & 10.26 & 618.00 \\
\hline
\end{tabular}

QWL stands for quality of work life, OC stands for organizational commitment and $\mathrm{N}$ stands for number of respondents of that particular company. Explanation: It can be seen in the above table that there are five IT companies who are generating highest revenues per employee compared to other companies. Eight companies fall in the category of Medium range in terms of generating revenue per employee. Eight Companies comes under the Low range in terms of revenue per employee. It can be seen that Company No. 2 falls in low range category in terms of revenue per employee with the mean score of QWL (61.13) and OC (63.38) and company No. 18 falls in High range category in the terms of revenue generating per employee with the low mean score value of QWL (59.43) and OC (58.13). Company no. 9 falls in low range category with the second highest mean scores of QWL among all large cap IT companies.

\subsection{Analysis of QWL and Commitment of Selected IT Companies by Using of ANOVA}

Following hypotheses are adopted as:

$\mathrm{H}_{01}$ : The mean scores of QWL are identical across all selected IT companies;

$\mathrm{H}_{02}$ : The mean scores of commitment are identical across all selected IT companies.

Analysis of variance is used to check the degree of variance between two or more groups in an experiment. In this study, ANOVA was used to analyse 
whether the levels of QWL and commitment differ among the selected IT companies (Table 3 and Table 4).

Table 3. Analysis of variances of QWL and OC of selected companies.

\begin{tabular}{ccccccc}
\hline & Sum of Squares & Df & Mean Square & F & Sig. \\
\hline \multirow{4}{*}{ Commitment } & Between Groups & 10089.635 & 20 & 504.482 & & \\
& Within Groups & 54815.704 & 597 & & 5.494 & 0.000 \\
& Total & 64905.339 & 617 & 91.819 & & \\
\multirow{2}{*}{ QWL } & Between Groups & 2515.074 & 20 & 125.754 & & \\
& Within Groups & 24042.122 & 597 & & 3.123 & 0.000 \\
& Total & 26557.196 & 617 & 40.272 & & \\
\hline
\end{tabular}

Explanation: It can be seen that the significance level in ANOVA table produced by SPSS is less than 0.01 (p $=0.01$ ) for both QWL and employee commitment, which rejects the null hypothesis. Hence, there is statistically significant difference among various selected IT companies. Hence, it can be clearly inferred that QWL and employee commitment are company specific. Organizational performance is checked by using revenue per employee of the company. The following Table 4 represents the average of 5 year's organizational performance of selected companies i.e. from year 2014-2018.

Table 4. Regression analysis of predicators of QWL on dependent variable OC of the selected companies.

\begin{tabular}{|c|c|c|c|c|c|}
\hline Name of Organisation & $\mathrm{RPE}$ (in crore) & & & & \\
\hline & & $\mathrm{R}$ & R square & $\mathrm{F}$ & Sig \\
\hline 1 & High Range & $0.198^{\mathrm{a}}$ & 0.039 & 1.547 & $0.221^{\mathrm{b}}$ \\
\hline 2 & High Range & $0.626^{\mathrm{a}}$ & 0.392 & 12.912 & $0.002^{\mathrm{b}}$ \\
\hline 3 & High Range & $0.296^{\mathrm{a}}$ & 0.087 & 3.065 & $0.09^{\mathrm{b}}$ \\
\hline 4 & High Range & $0.671^{\mathrm{a}}$ & 0.45 & 25.11 & $0^{\mathrm{b}}$ \\
\hline 5 & High Range & $0.204^{\mathrm{a}}$ & 0.042 & 2.989 & $1.02^{\mathrm{b}}$ \\
\hline 6 & Low Range & $0.550^{\mathrm{a}}$ & 0.303 & 12.201 & $0.004^{\mathrm{b}}$ \\
\hline 7 & Low Range & $0.398^{\mathrm{a}}$ & 0.158 & 6.779 & $0.013^{\mathrm{b}}$ \\
\hline 8 & Low Range & $0.687^{\mathrm{a}}$ & 0.472 & 24.113 & $0^{\mathrm{b}}$ \\
\hline 9 & Low Range & $0.541^{\mathrm{a}}$ & 0.293 & 10.366 & $0.004^{\mathrm{b}}$ \\
\hline 10 & Low Range & $0.389^{\mathrm{a}}$ & 0.152 & 3.754 & $0.066^{\mathrm{b}}$ \\
\hline 11 & Low Range & $0.533^{\mathrm{a}}$ & 0.284 & 13.101 & $0.001^{\mathrm{b}}$ \\
\hline 12 & Low Range & $0.517^{\mathrm{a}}$ & 0.267 & 10.222 & $0.003^{\mathrm{b}}$ \\
\hline 13 & Low Range & $0.704^{\mathrm{a}}$ & 0.495 & 21.59 & $0^{\mathrm{b}}$ \\
\hline 14 & Medium Range & $0.542^{\mathrm{a}}$ & 0.294 & 10 & $0.004^{\mathrm{b}}$ \\
\hline 15 & Medium Range & $0.326^{\mathrm{a}}$ & 0.106 & 3.445 & $0.074^{\mathrm{b}}$ \\
\hline 16 & Medium Range & $0.099^{\mathrm{a}}$ & 0.1 & 0.275 & $0.604^{\mathrm{b}}$ \\
\hline 17 & Medium Range & $0.725^{\mathrm{a}}$ & 0.525 & 30.995 & $0^{\mathrm{b}}$ \\
\hline 18 & Medium Range & $0.868^{\mathrm{a}}$ & 0.753 & 73.337 & $0^{\mathrm{b}}$ \\
\hline 19 & Medium Range & $0.469^{\mathrm{a}}$ & 0.22 & 8.445 & $0.007^{\mathrm{b}}$ \\
\hline 20 & Medium Range & $0.194^{\mathrm{a}}$ & 0.038 & 0.469 & $0.596^{\mathrm{b}}$ \\
\hline
\end{tabular}

Explanation: Table 4 explains the number of respondents of each identical company in which regression analysis is used. Table 4 explains range of the organisation by revenue per employee and $\mathrm{R}$ value indicates the effect of QWL on OC. Regression analysis of each identical companies is done with the dependent variable OC and independent variables QWL. R value indicates the relationship of impact of QWL on OC of the identical IT companies, who represents their revenue per employee in the Table 4. 
$\mathrm{H}_{03}$ : There is no significant relation of Organizational Performance with QWL and Organizational Commitment.

It can be seen that two medium range companies have better $\mathrm{R}$ value ( $\mathrm{R}=$ 0.868 and $\mathrm{R}=0.725)$ than the High range companies $(\mathrm{R}=0.671$ and $\mathrm{R}=0.626)$. On the other hand, there are two Low range companies in terms of revenue per employee with relative high $R$ value $(R=0.704$ and $R=0.687)$. In regression analysis, QWL is used as independent variables and $\mathrm{OC}$ as dependent variable. Findings from the above results indicate that there is a significant relationship between quality of work life and organizational commitment with the revenue per employee of the IT companies.

The results show that there are five large cap IT companies who fall in high range in terms of revenue per employee in which only two large caps IT companies proves a positive relationship of QWL and OC with OP at the level of five percent significance. It means if employees continue their commitment towards organization, it increases revenue per employee [52]. On the other side, medium range of the IT companies indicates that there is also positive relation of QWL and $\mathrm{OC}$ with revenue per employee at the level of five percent significance. In the end, we can conclude that revenue per employee is affected by QWL and OC in large IT companies in India.

\section{Conclusions}

An Organization provides better QWL and gives better training to the employees to get efficient and effective results in the form of growth and profitability for the organization. Organization strives to retain the employees and does the needful for the employees to achieve goals and objectives of the organization. In this study, financial performance of the organization is measured through revenue per employee. The study proves that QWL and organizational commitment increases the financial performance of the organization in terms of revenue per employee. Happy and satisfied employees make the organization's culture better and generate more revenue. The study discloses that QWL and organizational commitment are positively co-related with the financial performance; this means that if managers work on the factors affecting QWL to enhance the organizational commitment, it should increase the revenue of the organization. But if some organizations are not showing positive co-relation of revenue per employee with QWL and OC, it means there are other factors too which affect revenue per employee. One of the key factors for the variance could be the difference in business profile of individual companies either in terms of revenue mix (linear versus non-linear) or in terms of percentage of employees deployed on site (client site) versus offshore, both of which have a direct impact on billing rates per hour charged by the company to its clients.

One limitation of this study is that primary data are taken from employees working out of India but revenue per employee is for the organization as a whole-taking into account the domestic revenues as well as exports divided by the total employees in India as well as abroad. 
The study reveals that committed employees and better QWL generate higher revenue per employee. Thus, it can be said that revenue per employee of a company depends upon effective work by employees for which organizations have to focus on better QWL, if an organization offers a conducive work environment like flexible working hours, work quality/difficulty in line with employee potential, clear career growth path for employees, appropriate work-life balance, adequate compensation, healthy organizational culture and healthy relationship between peer and superiors. The quality of work life improves without incurring extra cost to organization. All the factors mentioned above help enhance the performance of the employees and directly impacts the performance of an organization in terms of revenue per employee. Organization offers better QWL to get back commitment from employees. The motive of organizations behind it is to raise profitability. Satisfied employees work happily and generate growth and profits for the organization, thus making the existence of an organization more sustainable. Employee wellbeing and their commitment improve the organizational performance. Performance of the employees would be better if better policies and programs related to QWL are implemented. Thus, it can be inferred that performance of the employees affects the organizational performance significantly.

This study helps the policy maker i.e. the human resource department of the companies to work on the dimensions of QWL and make necessary changes to get committed employees. Main motive of an organization should not be to just generate profits but to have satisfied employees as well. This study will help in increasing the organizational commitment of employees leading to better organizational performance. The findings of this study can help the managers in understanding the sentiments of the employees and focusing on the QWL according to the needs and wants of today's employees in the organization [53] [54]. Managers can work on the variables which are significantly related to QWL and organizational commitment. After this study, IT sector should do an evaluation of the QWL that they are offering and fill the gap between what they offer and what employees' need [55].

\section{Conflicts of Interest}

The authors declare no conflicts of interest regarding the publication of this paper.

\section{References}

[1] Van De Voorde, K., Paauwe, P. and Van Veldhoven, M. (2011) Employee Well-Being and the HRM-Organizational Performance Relationship: A Review of Quantitative Studies. International Journal of Management Reviews, 14, 391-407. https://doi.org/10.1111/j.1468-2370.2011.00322.x

[2] Hakanen, J.J., Peeters, M.C.W. and Schaufeli, W.B. (2018) Different Types of Employee Well-Being across Time and Their Relationships with Job Crafting. Journal of Occupational Health Psychology, 23, 289-301. 
https://doi.org/10.1037/ocp0000081

[3] Boxall, P., Guthrie, J.P. and Paauwe, J. (2016) Editorial Introduction: Progressing Our Understanding of the Mediating Variables Linking HRM, Employee Well-Being and Organisational Performance. Human Resource Management Journal, 26, 103-111. https://doi.org/10.1111/1748-8583.12104

[4] Schaufeli, W., Taris, T. and Van Rhenen, W. (2007) Workaholism, Burnout, and Work Engagement: Three of a Kind or Three Different Kinds of Employee Well-Being? Apllied Psychology, 57, 173-203.

https://doi.org/10.1111/j.1464-0597.2007.00285.x

[5] Porter, M.E. and Kramer, M.R. (2019) Creating Shared Value. In: Lenssen, G. and Smith, N., Eds., Managing Sustainable Business, Springer, Dordrecht, 323-346.

https://doi.org/10.1007/978-94-024-1144-7_16

[6] Bedanand, U., Rahat, M. and Blount, Y. (2014) Association between Performance Measurement Systems and Organisational Effectiveness. International Journal of Operations \& Production Management, 34, 853-875.

https://doi.org/10.1108/IJOPM-02-2013-0091

[7] Mallick, E., Pradhan, R.K., Tewari, H.R. and Jena, L.K. (2014) Organizational Citizenship Behaviour, Job Performance and HR Practices: A Relational Perspective. Management and Labour Studies, 39, 449-460. https://doi.org/10.1177/0258042X15578023

[8] Dhar, R.L. (2015) Service Quality and the Training of Employees: The Mediating Role of Organizational Commitment. Tourism Management, 46, 419-430. https://doi.org/10.1016/j.tourman.2014.08.001

[9] Kang, H.J., Gatling, A. and Kim, J. (2015) The Impact of Supervisory Support on Organizational Commitment, Career Satisfaction, and Turnover Intention for Hospitality Frontline Employees. Journal of Human Resources in Hospitality \& Tourism, 14, 68-89. https://doi.org/10.1080/15332845.2014.904176

[10] McCall, S. (1975) Quality of Life. Social Indicators Research, 2, 229-248. https://doi.org/10.1007/BF00300538

[11] Al Shobaki, M.J., Abu-Naser, S.S., Salama, A.A., AlFerjany, A.A.M. and Amuna, Y.M.A. (2018) The Role of Measuring and Evaluating Performance in Achieving Control Objectives-Case Study of "Islamic University". International Journal of Engineering and Information Systems, 2, 106-118.

[12] Drobnič, S., Beham, B. and Präg, P. (2010) Good Job, Good Life? Working Conditions and Quality of Life in Europe. Social Indicators Research, 99, 205-225. https://doi.org/10.1007/s11205-010-9586-7

[13] Arulsenthilkumar, S., Punitha, N., Nadu, T. and Trainer, S.S. (2008) Quality of Work Life for Employees in Supermarkets with Reference to Comibatore. National Monthyly Refereed Journal of Reasearch in Commerce \& Management, 1, 108-116.

[14] Duyan, E.C., Aytaç, S., Akyildiz, N. and Van Laar, D. (2013) Measuring Work Related Quality of Life and Affective Well-Being in Turkey. Mediterranean Journal of Social Sciences, 4, 105-116.

[15] Saha, G. and Roy, D. (2007) Changes in Women's Dress Preference: An in-Depth Study Based on Lifestyle and Age. South Asian Journal of Management, 14, 90-105.

[16] Arora, D. (2005) Foreign Multinationals in India: Adapting to India's Work Culture and Management Practices. Internationale Geschäftstätigkeiten in Asien: München und Mering, Rainer Hampp, Germany, 1-37.

[17] Oshagbemi, T. (2000) Gender Differences in the Job Satisfaction of University 
Teachers. Women in Management Review, 15, 331-343. https://doi.org/10.1108/09649420010378133

[18] Argentero, P., Miglioretti, M. and Angilletta, C. (2007) Quality of Work Life in a Cohort of Italian Health Workers. Giornale Italiano Di Medicina Del Lavoro Ed Ergonomia, 29, A50-A54.

[19] Michalos A.C. (2017) Education, Happiness and Wellbeing. In: Connecting the Quality of Life Theory to Health, Well-Being and Education, Springer, Cham. https://doi.org/10.1007/978-3-319-51161-0

[20] Macdougall, H., O’Halloran, P., Sherry, E. and Shields, N. (2016) Needs and Strengths of Australian Para-Athletes: Identifying Their Subjective Psychological, Social, and Physical Health and Well-Being. The Sport Psychologist, 30, 1-12. https://doi.org/10.1123/tsp.2015-0006

[21] Martel, J.-P. and Dupuis, G. (2006) Quality of Work Life: Theoretical and Methodological Problems, and Presentation of a New Model and Measuring Instrument. Social Indicators Research, 77, 333-368. https://doi.org/10.1007/s11205-004-5368-4

[22] Asgari, M.H. and Dadashi, M.A. (2011) Determining the Relationship between Quality of Work Life (QWL) and Organizational Commitment of Melli Bank Staff in West Domain of Mazandaran in 2009-2010. Australian Journal of Basic and Applied Sciences, 5, 682-687.

[23] Chumg, H.F., Cooke, L., Fry, J. and Hung, I.-H. (2015) Factors Affecting Knowledge Sharing in the Virtual Organisation: Employees' Sense of Well-Being as a Mediating Effect. Computers in Human Behavior, 44, 70-80. https://doi.org/10.1016/j.chb.2014.11.040

[24] Martyr, A., Nelis, S.M., Quinn, C., Wu, Y.T., Lamont, R.A., Henderson, C., et al. (2018) Living Well with Dementia: A Systematic Review and Correlational Meta-Analysis of Factors Associated with Quality of Life, Well-Being and Life Satisfaction in People with Dementia. Psychological Medicine, 48, 2130-2139. https://doi.org/10.1017/S0033291718000405

[25] Horská, E. and Krasnodębski, A. (2009) The Selected Theoretical and Practical Viewpoints to Managing Cultural Diversity in the International Business. Agricultural Economics, 55, 368-374. https://doi.org/10.17221/6/2009-AGRICECON

[26] Gilgeous, V. (1998) Manufacturing Managers: Their Quality of Working Life. Integrated Manufacturing Systems, 9, 173-181.

https://doi.org/10.1108/09576069810210466

http://www.scopus.com/inward/record.url?eid=2-s2.0-0031623664\&partnerID=tZO $\underline{\mathrm{tx} 3 \mathrm{y} 1}$

[27] Johnson, B.G. and Solon, G. (2016) American Economic Association Estimates of the Direct Effects of Comparable Worth Policy. The American Economic Review, 76, 1117-1125.

[28] Rice, R.W., Mcfarlin, D.B., Hunt, R.G. and Near, J.P. (1985) Organizational Work and the Perceived Quality of Life: Toward a Conceptual Model State University of New York at Buffalo. Academy of Management Review, 10, 296-310. https://doi.org/10.5465/amr.1985.4278215

[29] Hamann, P.M., Schiemann, F., Bellora, L. and Guenther, T.W. (2013) Exploring the Dimensions of Organizational Performance A Construct Validity Study. Organizational Research Methods, 16, 67-87. https://doi.org/10.1177/1094428112470007

[30] Islam, Z. and Siengthai, S. (2009) Quality of Work Life and Organizational Perfor- 
mance : Empirical Evidence from Dhaka Export Processing Zone. ILO Conference on Regulating for Decent Work, Geneva, 1-19.

http://www.ilo.org/legacy/english/protection/travail/pdf/rdwpaper37a.pdf

[31] Pradhan, S. and Pradhan, R.K. (2015) An Empirical Investigation of Relationship among Transformational Leadership, Affective Organizational Commitment and Contextual Performance. Vision: The Journal of Business Perspective, 19, 227-235. https://doi.org/10.1177/0972262915597089

[32] Seashore, S.E. and Yuchtman, E. (2016) Factorial Analysis of Organizational Performance. Administrative Science Quarterly, 12, 377-395. https://doi.org/10.2307/2391311

[33] Khodadadi, S., Darzian, A. and Pasand, M. (2014) Investigating the Quality of Work Life Dimensions Effect on the Employees' Job Satisfaction (Case Study: Shustar's Shohada Hospital). 2, 177-183.

[34] Golmohammadzadeh, S., Ghanbari, S., Valiki, S.R.H. and Hasannia, H. (2015) Impact of Vermicompost and Chemical Fertilizer on Yield, Growth and Essential Oil of Garlic (Allium sativum L.). International Journal of Life Sciences, 9, 44-48. https://doi.org/10.3126/ijls.v9i4.12675

[35] Arif, S. and Ilyas, M. (2013) Quality of Work-Life Model for Teachers of Private Universities in Pakistan. Quality Assurance in Education, 21, 282-298. https://doi.org/10.1108/QAE-Feb-2012-0006

[36] Emadzadeh, D.M.K., Khorasani, M. and Nematizadeh, F. (2012) Assessing the Quality of Work Life of Primary School Teachers in Isfahan City. Interdisciplinary Journal of Contemporary Research in Business, 3, 438-448.

[37] Lusthaus, C. and Adrien, M. (1998) Organizational Assessment : A Review of Experience. Universalia Occasional Paper, No. 31.

[38] Moses, B. (1999) Career Planning Mirrors Social Change. The Globe and Mail. Retrieved January, 18, 2001.

[39] Reddy, L.M. and Reddy, M.P. (2010) Quality of Work Life of Employees: Emerging Dimensions. Asian Journal of Management Research, 1, 827-839.

[40] Lebas, M. and Euske, K. (2006) A Conceptual and Operational Delineation of Performance. Business Performance Measurement. Theory and Pratice, 1, 65-79. https://doi.org/10.1017/CBO9780511753695.006

[41] Weisboard, M.R. (2007) Productive Workplace: Organizing and Managing for Dignity Meaning and Community. 5th Edition, Jossey-Bass, New York.

[42] Kaplan, R.S. and Norton, D. (1992) Putting the Balanced Scorecard to Work. Harvard Business Review, 71, 134-147.

[43] Nolan, C.T. and Garavan, T.N. (2016) Human Resource Development in SMEs: A Systematic Review of the Literature. International Journal of Management Reviews, 18, 85-107. https://doi.org/10.1111/ijmr.12062

[44] Horska, E. and Glova, J. (2014) Patterns of Business Internationalisation in the Czech Republic: Empirical Results from the V4 Survey.

[45] Krause, H.U. and Arora, D. (2012) Controlling-Kennzahlen-Key Performance Indicators: Zweisprachiges Handbuch Deutsch/Englisch-Bi-Lingual Compendium German/English. Walter de Gruyter, Berlin.

[46] Lau, R.S.M. (2000) Quality of Work Life and Performance-An Ad Hoc Investigation of Two Key Elements in the Service Profit Chain Model. International Journal of Service Industry Management, 11, 422-437.

https://doi.org/10.1108/09564230010360164 
[47] Huang, L.C., Ahlstrom, D., Lee, A.Y.P., Chen, S.Y. and Hsieh, M.J. (2016) High Performance Work Systems, Employee Well-Being, and Job Involvement: An Empirical Study. Personnel Review, 45, 296-314. https://doi.org/10.1108/PR-09-2014-0201

[48] Mortazavi, S. (2012) The Role of the Psychological Capital on Quality of Work Life and Organization Performance. Interdisciplinary Journal of Contemporary Research in Business, 4, 206-218.

[49] Agarwal, K.N. (2008) Competitive Intelligence in Business Decisions: An Overview. IEEE Engineering Management Review, 36, 17. https://doi.org/10.1109/EMR.2008.4648886

[50] Horska, E., Urgeova, J. and Prokeinova, R. (2011) Country of Origin and Quality Perception and Its Impact on Consumer Buying Decision: Case of Slovakia and Poland. Jezkyi Publikaciji, 177, 75-85.

[51] Singh, T. and Srivastav, S.K. (2012) Qwl and Organization Efficiency: A Proposed Framework. Journal of Strategic Human Resource Management, 1, 1-13.

[52] Shee, H.K. and Pathak, R.D. (2006) Managing People and Technology for Enhancing Competitiveness. Journal of Transnational Management, 11, 63-80. https://doi.org/10.1300/J482v11n01_05

[53] Yadav, R. and Khanna, A. (2014) Literature Review on Quality of Work Life and Their Dimensions. IOSR Journal of Humanities and Social Science (IOSR-JHSS), 19, 71-80. https://doi.org/10.9790/0837-19957180

[54] Yadav, R., Khanna, A. and Singh, D. (2017) Exploration of Relationship between Stress and Spirituality Characteristics of Male and Female Engineering Students: A Comprehensive Study. Journal of Religion and Health, 56, 388-399. https://doi.org/10.1007/s10943-015-0174-7

[55] Yadav, R. and Khanna, A. (2014) Employees' Satisfaction on Quality of Worklife at State Bank of India. International Conference on Humanities, Literature and Management, Dubai, 9-10 January 2015. 


\section{Appendix}

Questionnaire to Measure Quality of work life Effectiveness

Declaration

I am Radha Yadav, Research Scholar, Indian Institute of Technology, Roorkee. My research topic is quality of work life of IT sector. Kindly spare your few minutes and provide your valuable responses to complete this questionnaire. The information given by you will be kept fully confidential and will be used only for research/academic work.

Personal Information

1) Name of the respondent (optional):-

2) Gender: - a) Male b) Female

3) Age: - a) 25 - 35 b) 35 - 45 c) above 45

4) Marital Status: - a) Married b) Unmarried c) Other

5) Work experience: - a) 1 year: b) 2 year c) 3 years

d) 4 years e) above 5 years

6) Qualification: - a) Graduate: b) Postgraduate: -

c) Professional Qualification:

7) Name of an organization: -

8) Annual Gross Income (in Rupees): -
a) 1.2 Lakh. - 2.5 Lakh
b) $2.5 \mathrm{Lakh}$ - 3.5 Lakh
c) 3.5 Lakh - 4.5 Lakh
d) 4.5 Lakh - 5.5 Lakh
e) above 5.5 Lacs

9) No. of jobs changed: - a) less than 2 b) more than 2

10) No. of Dependent Adult: -

a) No dependent

b) 1 dependent or more than 1

11) Designation: -

12) Email Id: -

13) Contact No.

14) Nationality: -

15) Spouse's income: -
a) 1.2 Lakh. - 2.5 Lakh
b) $2.5 \mathrm{Lakh}-3.5 \mathrm{Lakh}$
c) 3.5 Lakh - 4.5 Lakh
d) 4.5 Lakh - $5.5 \mathrm{Lakh}$
e) above 5.5 Lacs

SCALE: 1 = strongly agree 2 = agree $3=$ nor agree neither disagree $4=$ disagree 5 = strongly disagree

\begin{tabular}{|c|c|c|c|c|c|c|}
\hline \multirow[t]{5}{*}{ S. No. } & Questions & \multicolumn{5}{|c|}{ Scale } \\
\hline & $\begin{array}{l}\text { Do you feel that you have to do your work especially well in order to } \\
\text { secure the continuity of your employment relationship? }\end{array}$ & 1 & 2 & 3 & 4 & 5 \\
\hline & $\begin{array}{l}\text { Do you miss the sense of security that comes with a permanent } \\
\text { employment relationship? }\end{array}$ & 1 & 2 & 3 & 4 & 5 \\
\hline & Does your job provide you a secure future? & 1 & 2 & 3 & 4 & 5 \\
\hline & Does your job provide you steady employment? & 1 & 2 & 3 & 4 & 5 \\
\hline
\end{tabular}




\section{Continued}

Are Layoffs avoided in your workplace?

Do you think about and do things related to work even in free time because your work is so interesting?

Are you able to see the results of the work you do?

$\begin{array}{lllll}1 & 2 & 3 & 4 & 5\end{array}$

Do you get the chance to make decisions on your job?

$\begin{array}{lllll}1 & 2 & 3 & 4 & 5\end{array}$

Do you get the chance to try something different?

$\begin{array}{lllll}1 & 2 & 3 & 4 & 5\end{array}$

Do you get the chance to make use of your best abilities?

$\begin{array}{lllll}1 & 2 & 3 & 4 & 5\end{array}$

Do you get the chance to develop new and better ways to do the job? $1 \begin{array}{lllll}1 & 2 & 3 & 4 & 5\end{array}$

Do you get the chance to work independently of others?

$\begin{array}{lllll}1 & 2 & 3 & 4 & 5\end{array}$

When your work seems difficult, do you receive support and encouragement from your superiors?

$\begin{array}{lllll}1 & 2 & 3 & 4 & 5\end{array}$

Do you feel that you are a valued by your co-worker?

$\begin{array}{lllll}1 & 2 & 3 & 4 & 5\end{array}$

Do you feel good spirit of cooperation among your co-workers?

$\begin{array}{lllll}1 & 2 & 3 & 4 & 5\end{array}$

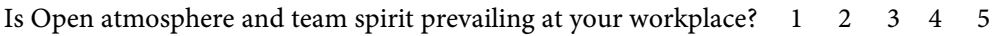

Is there an inspiring atmosphere at your workplace?

$\begin{array}{lllll}1 & 2 & 3 & 4 & 5\end{array}$

Is there gossiping and envy at your workplace?

$\begin{array}{lllll}1 & 2 & 3 & 4 & 5\end{array}$

Does your Work pressure spoil the work atmosphere?

$\begin{array}{lllll}1 & 2 & 3 & 4 & 5\end{array}$

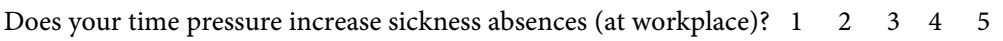

Do you have time to do your work as well and carefully as you would like to?

$\begin{array}{lllll}1 & 2 & 3 & 4 & 5\end{array}$

Is there very little social interaction because of time pressure?

$\begin{array}{lllll}1 & 2 & 3 & 4 & 5\end{array}$

Is there burnout at your workplace?

$\begin{array}{lllll}1 & 2 & 3 & 4 & 5\end{array}$

Do you do mistakes cause of pressure at your workplace?

$\begin{array}{lllll}1 & 2 & 3 & 4 & 5\end{array}$

Does your work contain tight time schedules?

$\begin{array}{lllll}1 & 2 & 3 & 4 & 5\end{array}$

Do you feel the safety of workers is a high priority for management where you work?

Do you feel, the safety and health conditions are good in your working place?

In the last 12 months, were you threatened or harassed in any other way by anyone while you were on the job?

Does your supervisor show appreciation for the contribution you make?

Are there few rewards for those who work here?

$\begin{array}{lllll}1 & 2 & 3 & 4 & 5\end{array}$

Don't you feel your efforts are rewarded the way they should be?

$\begin{array}{lllll}1 & 2 & 3 & 4 & 5\end{array}$

Is a communication seemed well within this organization?

$\begin{array}{lllll}1 & 2 & 3 & 4 & 5\end{array}$

Do you have enough information to get the job done?

$\begin{array}{lllll}1 & 2 & 3 & 4 & 5\end{array}$

Is communication open at your workplace?

$\begin{array}{lllll}1 & 2 & 3 & 4 & 5\end{array}$

Are the chances for promotion good?

$\begin{array}{lllll}1 & 2 & 3 & 4 & 5\end{array}$

Do you have an opportunity to develop your own special abilities?

$\begin{array}{lllll}1 & 2 & 3 & 4 & 5\end{array}$ 


\section{Continued}

Does your organization offer your opportunities to grow and learn new skills?

Do you plan to stay with this organization for the foreseeable future? $1 \quad 2 \quad 3 \quad 4 \quad 4 \quad 5$

Are you satisfied with the fairness of promotion procedure in your company?

Is Grievances handling procedure effectively work to sort out grievances in your organization?

Do you receive appropriate pay for your job according to work assigned to do?

Are amounts of wages and salaries and personal bonuses in public knowledge at your workplace?

Do you feel unappreciated by the organization when I think about what they pay?

You would be very happy to spend the rest of your career with this organization.

$\begin{array}{lllll}1 & 2 & 3 & 4 & 5\end{array}$

You really feel as if this organization's problems are your own.

$\begin{array}{lllll}1 & 2 & 3 & 4 & 5\end{array}$

You do not feel a strong sense of "belonging" to your

organization.

$\begin{array}{lllll}1 & 2 & 3 & 4 & 5\end{array}$

You do not feel "emotionally attached" to this organization.

$\begin{array}{lllll}1 & 2 & 3 & 4 & 5\end{array}$

You do not feel like "part of the family" at my organization.

$\begin{array}{lllll}1 & 2 & 3 & 4 & 5\end{array}$

This organization has a great deal of personal meaning for you.

$\begin{array}{lllll}1 & 2 & 3 & 4 & 5\end{array}$

Right now, staying with organization is a matter of necessity as much as desire.

It would be very hard for you to leave organization right now, even if ${ }_{1} \quad 2 \quad 3 \quad \begin{array}{llll}{ }_{1} & 2 & 4\end{array}$ you wanted to.

Too much of your life would be disrupted if you decided you wanted ${ }_{1} \quad 2 \quad 3 \quad 3 \quad 4 \quad 5$ to leave your organization now.

You feel that you have too few options to consider leaving this organization.

If you had not already put so much of yourself into this organization, you might consider working elsewhere.

One of the few negative consequences of leaving this organization would be the scarcity of available alternatives.

You do not feel any obligation to remain with your current employer.

Even if it were to your advantage, you do not feel it would be right to leave your organization now.

You would feel guilty if you left your organization now.

$\begin{array}{lllll}1 & 2 & 3 & 4 & 5\end{array}$

This organization deserves your loyalty.

$\begin{array}{lllll}1 & 2 & 3 & 4 & 5\end{array}$

You would not leave your organization right now because I have a

sense of obligation to the people in it.

$\begin{array}{lllll}1 & 2 & 3 & 4 & 5\end{array}$

You owe a great deal to your organization.

$\begin{array}{lllll}1 & 2 & 3 & 4 & 5\end{array}$

All in all, how satisfied would you say you are with your job?

$\begin{array}{lllll}1 & 2 & 3 & 4 & 5\end{array}$ 


\section{Continued}

SCALE: $1=$ sometimes $2=$ rarely $3=$ never $4=$ often $5=$ always

During the past 12 months, how often have you had trouble going to ${ }_{1} \quad 2 \quad \begin{array}{lllll} & 2 & 4 & 5\end{array}$ sleep or staying asleep?

How often do you work at home as part of your job?

$\begin{array}{lllll}1 & 2 & 3 & 4 & 5\end{array}$

How often do the demands of your job interfere with your family life?

How often find it difficult to cope at your work?

How often do you have to give up breaks because of workloads?

How often do you interrupt your work because of work related inquiries, calls, etc.?

How often do you to stretch your working day to get all the work done?

How often do you work extra hours beyond your usual schedule?

How hard is it to take time off during your work to take care of personal or family matters?

\section{FRINGE BENEFITS SCALE: YES/NO}

Does your organisation provide conveyance, tour, travel (including foreign travel) for official purpose?

Does your organisation provide facility of hotel, boarding and lodging for official purpose?

Does your organisation provide you paid holidays?

Does your organisation provide transport facility?

Does your organisation provide Expenditure on employee's welfare?

Does your organisation provide Medical expenses < Rs. 15,000?

Does your organisation provide Contribution by the employer to an approved superannuation fund?

Does your organisation provide use of telephone (including mobile phone) other than expenditure on leased telephone lines?

Does your organisation provide Facility of interest-free or concessional housing loan?

Does your organisation provide Facility of interest-free or concessional personal loan?

Does your organisation provide house rent allowance? 